\title{
GABA requires GLP-1R to exert its pancreatic function during STZ challenge
}

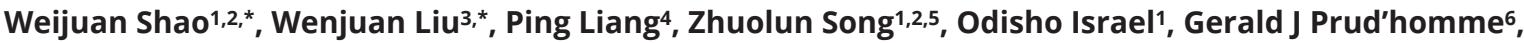 \\ Qinghua Wang2,3,6 and Tianru Jin1,2,5 \\ 1'Divsion of Advanced Diagnostics, Toronto General Hospital Research Institute, University Health Network, Toronto, Canada \\ 2Banting and Best Diabetes Centre, Department of Medicine, University of Toronto, Toronto, Canada \\ ${ }^{3}$ Department of Endocrinology and Metabolism, Huashan Hospital, Fudan University, Shanghai, China \\ ${ }^{4}$ Department of Biological Sciences, Brock University, St. Catherine, Canada \\ 5Department of Physiology, University of Toronto, Toronto, Canada \\ ${ }^{6}$ Keenan Research Centre for Biomedical Science, St. Michael's Hospital, Toronto, Canada
}

Correspondence should be addressed to Q Wang or T Jin: qinghua.wang@utoronto.ca or tianru.jin@utoronto.ca

*(W Shao and W Liu contributed equally to this work)

\begin{abstract}
Gamma-aminobutyric acid (GABA) administration attenuates streptozotocin (STZ)-induced diabetes in rodent models with unclear underlying mechanisms. We found that GABA and Sitagliptin possess additive effect on pancreatic $\beta$-cells, which prompted us to ask the existence of common or unique targets of GLP-1 and GABA in pancreatic $\beta$-cells. Effect of GABA on expression of thioredoxin-interacting protein (TxNIP) was assessed in the INS-1 832/13 (INS-1) cell line, WT and GLP-1 $R^{-/-}$mouse islets. GABA was also orally administrated in STZ-challenged WT or GLP-1 $R^{-/-}$mice, followed by immunohistochemistry assessment of pancreatic islets. Effect of GABA on Wnt pathway effector $\beta$-catenin ( $\beta$-cat) was examined in INS-1 cells, WT and GLP-1R-/- islets. We found that GABA shares a common feature with GLP-1 on inhibiting TXNIP, while this function was attenuated in GLP-1 $R^{-/-}$islets. In WT mice with STZ challenge, GABA alleviated several 'diabetic syndromes', associated with increased $\beta$-cell mass. These features were virtually absent in GLP-1R $R^{-/-}$mice. Knockdown TxNIP in INS-1 cells increased GLP-1R, $P d x 1, N k x 6.1$ and Mafa levels, associated with increased responses to GABA or GLP-1 on stimulating insulin secretion. Cleaved caspase-3 level can be induced by high-glucose, dexamethasone, or STZ in INS-1 cell, while GABA treatment blocked the induction. Finally, GABA treatment increased cellular cAMP level and $\beta$-cat 5675 phosphorylation in WT but not GLP-1 $R^{-/-}$islets. We, hence, identified TxNIP as a common target of GABA and GLP-1 and suggest that, upon STZ or other stress challenge, the GLP-1R-CAMP- $\beta$-cat signaling cascade also mediates beneficial effects of GABA in pancreatic $\beta$-cell, involving TxNIP reduction.
\end{abstract}

\author{
Key Words \\ - $\beta$-catenin \\ - GLP-1R \\ - pancreatic $\beta$-cells \\ and Wnt signaling
}

- GABA

- TxNIP

\section{Introduction}

Gamma-aminobutyric acid (GABA) is mainly produced in the brain, recognized as an inhibitory neurotransmitter. It is also produced in certain peripheral tissues, and its signaling is involved in various physiological functions
(Xiang et al. 2007, Tian et al. 2013, Xu et al. 2016, Feng et al. 2017, Januzi et al. 2018). In pancreatic islets, GABA inhibits glucagon secretion from pancreatic $\alpha$-cells but stimulates insulin secretion from pancreatic $\beta$-cells 
(Xu et al. 2006). We have reported previously that GABA administration exhibited protective effects on pancreatic $\beta$-cells and reversed 'diabetic syndromes' in mice induced by streptozotocin (STZ) challenge (Purwana et al. 2014). Such $\beta$-cell beneficial effect of GABA has been drawing global attention, while the underlying mechanism is unclear or even controversial. For example, two recent studies claimed the $\alpha$-cell to $\beta$-cell trans-differentiation feature of GABA administration or GABAergic signal activation (Ben-Othman et al. 2017, Li et al. 2017), which was not supported by other recent investigations (Ackermann et al. 2018, van der Meulen et al. 2018). Nevertheless, the protective effects of GABA in STZ-treated rodent models were observed by multiple investigations (Purwana et al. 2014, Feng et al. 2017, Liu et al. 2017, Kim et al. 2018). A more recent study also showed the $\beta$-cell proliferative effect of GABA, although GABA treatment did not overcome impaired glucose homeostasis induced by high fat diet feeding (Untereiner et al. 2019).

Sitagliptin is a type 2 diabetes (T2D) therapeutic agent, which prevents degradation of native incretin hormones, including glucagon-like peptide-1 (GLP-1) and gastric inhibitory polypeptide (GIP). Although GLP-1 receptor (GLP-1R) agonists are approved T2D drugs as well, therapeutic effect of GLP-1R agonists or sitagliptin in type 1 diabetes (T1D) is not appreciable (Pettus et al. 2013). We found recently that combined use of GABA and sitagliptin increased $\beta$-cell mass in STZ-induced T1D mouse model (Liu et al. 2017). These observations made us to wonder whether novel T1D therapy can be developed with combined use of GABA and GLP-1-based drugs (Jin \& Weng 2016).

To develop such therapy, it is necessary to conduct objective-driven analyses for determining the existence of overlapping as well as unique functions of GLP-1 and GABA in pancreatic islets. We show here that, in $\beta$-cells, GABA shares a common feature with GLP-1: inhibition of the glucotoxicity mediator thioredoxin-interacting protein (TxNIP), especially after high glucose (HG) challenge.

Proteasomal mediated TxNIP degradation can be facilitated by cAMP activation or GLP-1 treatment, demonstrated by Chen et al. first and later by our team (Chen et al. 2006, Shao et al. 2010). Indeed, we observed that GLP-1 or its based drug exenatide (exendin-4) can reduce TxNIP level in a pancreatic $\beta$-cell line or mouse islets cultured with high glucose $(\mathrm{HG},=$ or $>25 \mathrm{mM})$, involving cAMP elevation (Shao et al. 2010). Cha-Molstad et al. showed that carbohydrate response element-binding protein (ChREBP) is among TxNIP transcriptional activators (Cha-Molstad et al. 2009). Furthermore, $\beta$-cell specific TxNIP knockout mice are resistant to STZ-induced diabetes (Chen et al. 2008). In the current study, we found that the feature of attenuating TxNIP in response to HG challenge by GLP- 1 is shared by GABA, with cAMP- $\beta$ catenin activation as the common downstream pathway. Importantly, the attenuation effect of GABA on TxNIP expression in response to $\mathrm{HG}$ challenge was attenuated at mRNA level and was not observed at protein level in $G L P-1 R^{-/-}$islets. We then conducted GABA administration in STZ-challenged mice, showing a modest but significant attenuation effect of oral GABA administration on 'diabetic syndromes' as well as the stimulatory effect on $\beta$-cell mass in WT WT mice. These effects were

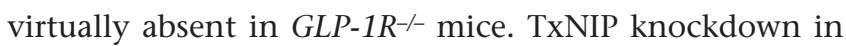
a rat pancreatic $\beta$-cell line increased GLP-1R expression, associated with increased responsiveness to GABA and GLP-1 treatment on insulin secretion. Thus, GLP-1R is likely required for GABA to exert its metabolic beneficial functions efficiently in mouse islets, especially after HG or STZ challenge.

\section{Materials and methods}

\section{Reagents and cell cultures}

GABA, the cell permeable proteasome inhibitor MG132 (carbobenzoxy-Leu-Leu-leucinal) and streptozocin (STZ) were products of Sigma-Aldrich, while GLP- $1_{7-37}$ was purchased from Abcam. The service for making GLP- $1_{28-36}$ was provided by Biomatik Corporation (Cambridge, ON, Canada) (Shao et al. 2013). Exendin-4 was from GenScript Co (Piscataway, NJ, USA) (Shao et al. 2010). The cAMP promoting agents forskolin and 3-isobutyl-1methylxanthine (IBMX) were also purchased from SigmaAldrich, while ethanol was utilized as the solvent for the in vitro cell culture experiments (Shao et al. 2010). The dosage for forskolin and IBMX in the in vitro cell culture work was $10 \mu \mathrm{M}$ and $1 \mu \mathrm{M}$, respectively. Pancreatic islets were isolated with the method utilizing collagenase in 8 -week-old male mice (Shao et al. 2015). The rat INS-1 832/13 cell line (INS-1 hereafter) or mouse islets were cultured in RPMI 1640 supplemented with 10\% FBS (Shao et al. 2015). Transfection of pGL3-TxNIP-LUC plasmid was achieved using polyethylenimine (Sigma-Aldrich) for $18 \mathrm{~h}$, followed by an indicated treatment for $4 \mathrm{~h}$ in the absence of serum (Ip et al. 2015). siRNA mediated TxNIP knockdown in the INS-1 cell line has been described previously (Masson et al. 2009, Shao et al. 2010). 


\section{Experimental mice}

$G L P-1 R^{-/-}$mice were kindly provided by Dr Daniel Drucker

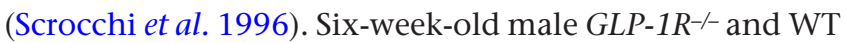
controls in C57BL/6 genetic background were utilized in indicated eight groups of studies (Hansotia et al. 2004). Briefly, mice were subject two rounds of STZ injection ( $0.1 \mathrm{mM}$ sodium citrate buffer as control), as illustrated in Fig. 3A. Along with the second STZ injection, GABA was provided in the drinking water for 13 weeks. During the 13-week period, body weight, random glucose and water consumption were recorded. Mice were killed for tissue weight measurement as well as immunohistochemistry study on pancreatic islets.

Oligonucleotide primers for $G L P-1 R^{-/}$mouse genotyping are listed in Supplementary Table 1A (see section on supplementary materials given at the end of this article). Mice were maintained at ambient room temperature and relative humidity of $50 \%$, with free access to food and water under a $12 \mathrm{~h}$ light: $12 \mathrm{~h}$ darkness cycle. STZ (125 mg/kg body weight) was i.p. injected as a freshly prepared solution in $0.1 \mathrm{mM}$ sodium citrate (pH 4.5). WT or GLP-1 $1 R^{-/}$mice were separated into four groups (Control, Control/GABA, STZ, and STZ/GABA). GABA solution $(6 \mathrm{mg} / \mathrm{mL})$ was supplied in drinking water (Liu et al. 2017). After the completion of the experiments, mice were killed by $\mathrm{CO}_{2}$ anesthesia. Animals were handled in strict accordance with good animal practice as defined by national and/or local animal welfare bodies. All animal work was approved by the Institutional Animal Care and Use Committee of the University Health Network. Pancreases were fixed in $4 \%$ paraformaldehyde overnight and embedded in paraffin for immune-histological analyses, as previously described (Shao et al. 2015).

\section{Insulin secretion measurement}

We followed the protocol by Deisl et al. for measuring insulin secretion (Deisl et al. 2013). INS-1 cells were subject to siRNA-mediated TxNIP knockdown for $48 \mathrm{~h}$, with scrambled siRNA as negative control. After an equilibration period of $1 \mathrm{~h}$ in Krebs-Ringer bicarbonate buffer (KRB) with $2.8 \mathrm{mM}$ glucose, cells were incubated for $20 \mathrm{~min}$ in fresh KRB containing $2.8 \mathrm{mM}$ glucose (defined as LG), $16.7 \mathrm{mM}$ glucose (defined as HG), or $16.7 \mathrm{mM}$ glucose plus $10 \mathrm{nM}$ GLP-1 or $50 \mu \mathrm{M}$ GABA. Supernatants were then harvested for insulin detection with the insulin enzyme immunoassay kit (AIS, Hong Kong) (Shao et al. 2015). For cellular insulin content determination, cells from each of the treatment groups were harvested, followed by insulin content detection using the previously mentioned kit. Values for cellular insulin content were normalized against cellular protein content. Insulin secretion in each group of cells was presented as percentage of cellular insulin content in $20 \mathrm{~min}$, as we reported previously (Shao et al. 2018).

\section{Western blotting and immunohistochemistry (IHC) studies}

Methods for Western blotting have been previously described (Shao et al. 2013), with primary antibodies listed in Supplementary Table 2. Insulin, glucagon, Pdx1, Nkx6.1, Ki67 and Pax6 expression in pancreatic islets was assessed by immunohistochemistry staining with correspondent antibodies (Supplementary Table 2). Insulin, glucagon, Pdx1, Nkx6.1, Ki67 and Pax6 primary antibody was diluted 1:1000, 1:1000, 1:400, 1:400, 1:200 and 1:500, respectively. For GLP-1R detection in mouse pancreatic islets, a MAB (Mab 7F38) described by Jensen et al. was utilized (Jensen et al. 2018). We followed the instruction utilizing $2 \mu \mathrm{g} / \mathrm{mL}$ of the Mab 7F38 antibody (Jensen et al. 2018) for GLP-1R immunohistochemistry staining, with the service provided by Pathology Research Program Laboratory of University Health Network (Toronto, ON, Canada).

$\beta$-cell mass for each pancreas was determined as the relative $\beta$-cell volume (by Image scope software) and the weight of the pancreas before fixation as we described previously (Shao et al. 2013). Total $\beta$-cell area and total pancreas mass for each animal was calculated as the sum of the determinations from each of the 4-6 segments of pancreas. Similar methods were applied for determining the $\alpha$-cell mass (Shao et al. 2013). For assessing Pdx1+, Nkx6.1+ $1^{+}$or Pax6 $6^{+}$insulin producing cells, we counted 1000-5000 $\beta$-cells per each mouse sample. For Ki67+ insulin producing cells, we counted 500-1000 $\beta$-cells per each mouse sample.

\section{RNA extraction, Northern blotting, reverse transcription, and real-time RT-PCR}

(qPCR)-Total RNA was isolated using the TRI reagent (Sigma-Aldrich). Northern blotting was conducted as previously described (Jin \& Drucker 1996). cDNA was generated using the High Fidelity cDNA Synthesis Kit (Applied Biosystems), as previously described (Shao et al. 2015). qPCR was performed with the use of SensiFAST TM SYBR® with a 7900 Fast Real-time PCR System (Applied Biosystems) (Shao et al. 2015). qRT-PCR primers utilized in this study are listed in Supplementary Table 1B. 


\section{Methods for RNAseq data analysis}

Raw RNAseq data in fastq format were obtained from The Center for Applied Genomics (Sickkids Hospital, Toronto, ON, Canada), and the data were analyzed using TopHat and Cufflinks packages (Trapnell et al. 2012) with mostly the default setting. Raw data were first subject to quality checking using fastqc to make sure all sequencing sets meet the quality requirements. Read mapping was done with the GRCm10 reference genome. For gene annotation, the GENECODE Release M12 (GRCm38.p5) data in gene transfer format (gtf) format was downloaded from the GENCODE website (https://www.gencodegenes.org). Identification of differentially expressed genes (DEGs) was performed using the cuffdiff module in the Cufflink package, which generate a list of DEGs for any pair of the four samples: WT mouse islet cells (WT), WT islet cells treated with GABA (WT+GABA), GLP-1R KO mouse islet cells (KO), and GLP-1R KO mouse islet cells with GABA treatment $(\mathrm{KO}+\mathrm{GABA})$. This DEG list was filtered by requiring sufficient reads for successful statistical test (teststatus as 'ok'). The raw Reads Per Kilobase Million (RPKM) values for these DEGs in all samples were retrieved from the output of the cufflinks module, and the lists were subject to further filtering generate the list of DEGs for downstream analysis. For a DEG to be included for each comparison between a pair of samples, the RPKM value had to be minimally 5 in at least one of the samples and the folder change between the two samples was required to show a minimal of 1.5 -fold difference.

\section{Luciferase (LUC) report gene construction and LUC assay}

The TxNIP-LUC fusion gene constructs were generated by PCR against the original plasmid, kindly provided by Dr Annath Shalev (University of Basel Medical School, Switzerland) (Cha-Molstad et al. 2009), followed by TA vector (Promega Corporation) cloning, DNA sequencing verification and sub-cloning of the Mlu I-Bgl II fragment into the pGL-3 basic LUC reporter construct (Promega Corporation). Oligonucleotide primers utilized for the cloning purpose are: TxNIP -1224 forward, 5' -GGACGCGTCCCACGCGTGTTTTCTAAACCG-3'; TxNIP -208 forward, 5' GGACGGGTCTCCAGAGCG CAACAACC-3'; and TxNIP +47 reverse, 5'-GCAGATCTCCGATCTCACAAGCACTCC-3'. LUC assay was conducted as previously described (Shao et al. 2015). Briefly, INS-1 cells were transfected with indicated reporter gene plasmid and cultured for $18 \mathrm{~h}$ in the presence of serum. Cells were then cultured with indicated treatment for $4 \mathrm{~h}$ in the absence of serum. Cells were harvested for LUC assay, normalized by cellular protein content.

\section{Cellular cAMP level measurement}

Cellular cAMP levels in the INS- 1 cell line were determined utilizing the commercial kit (510040) from Cayman Chemical, following the manufacturer's instruction.

\section{Generation of heat-maps}

The cut-off for gene selection for comparison was 10 fragments per kilobase million mapped reads (FPKM), as stated. Heatmaps in $\log _{10}$ scale were generated utilizing the $\mathrm{MeV}$ program.

\section{Statistics}

Results of insulin secretion are expressed as mean \pm s.E.M., and all other results are expressed as mean \pm s.D. Statistical significance was assessed by one-way ANOVA or $t$-test. $P$ value less than 0.05 was considered as statistically significant.

\section{Results}

\section{GABA or GLP-1 treatment reduces TXNIP level in mouse islets}

cAMP elevation or GLP-1 treatment has been shown to facilitate TxNIP protein degradation. To assess whether cAMP elevation can repress TxNIP expression at mRNA level, we treated INS-1 cells in the absence of serum with $10 \mu \mathrm{M}$ forskolin and $1 \mu \mathrm{M}$ IBMX, followed by Northern blotting and qRT-PCR. TxNIP level was increased 4-fold or higher along with glucose level elevation, while forskolin/ IBMX treatment reduced its level in INS-1 cells cultured with $25 \mathrm{mM}$ glucose (defined as HG for this figure), in a time-dependent manner (Fig. 1A and B).

GLP-1 can stimulate cAMP-PKA- $\beta$-catenin ( $\beta$-cat) signaling in mouse islets (Liu \& Habener 2008), while such feature was shared with the C-terminal fragment GLP- $1_{28-36}$ (Chiang et al. 2013, Shao et al. 2013). We show here that HG-induced TxNIP expression in INS-1 cells and WT mouse islets (Fig. 1C and D) can be attenuated by GABA, GLP-1, or GLP- $1_{28-36}$, indicating that attenuating HG-induced TxNIP expression is a feature shared by GLP-1 and GABA. In GLP-1 $R^{-/}$mouse islets, GABA or GLP- $1_{28-36}$, but not native GLP-1, repressed HG-induced 
A

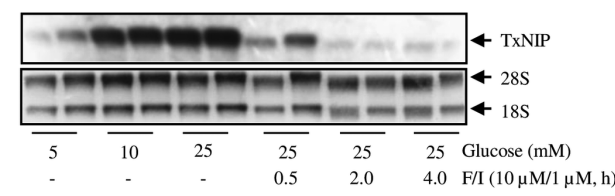

B INS-1 cells

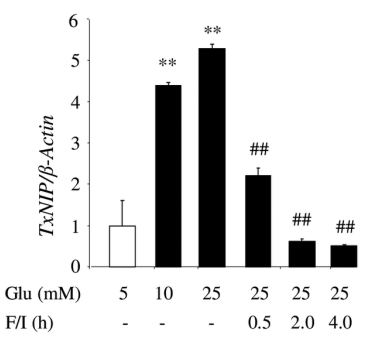

F

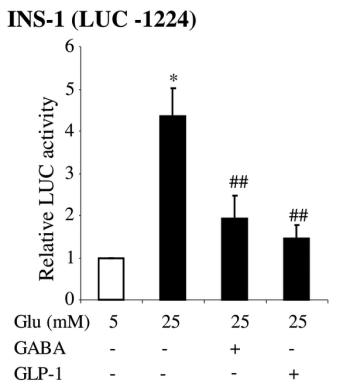

C INS-1 cells

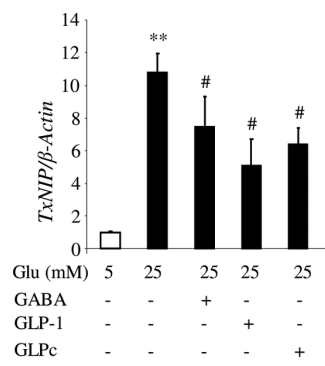

G

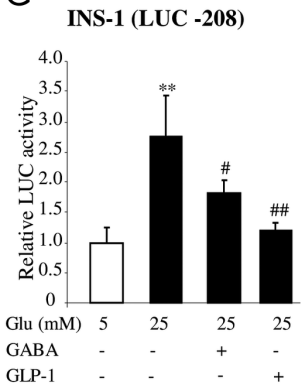

D Mouse Islets

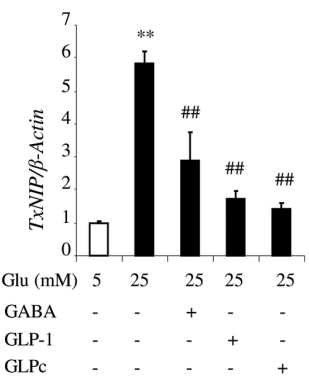

H INS-1 cells

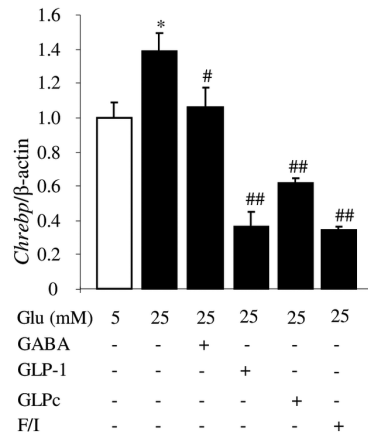

$\mathrm{E}_{G L P-1 r^{\prime} \text { - Islets }}$

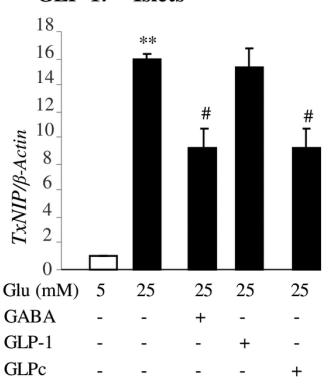

| Mouse islets

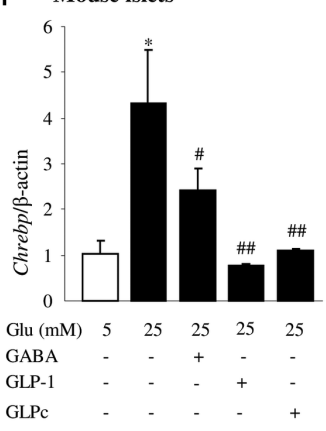

\section{Figure 1}

GABA or GLP-1 treatment reduces TXNIP level in INS-1 cells and mouse islets. (A and B) Northern blotting (A) and qRT-PCR (B) show the stimulatory effect of high glucose (HG, $25 \mathrm{mM})$ and the attenuation effect of forskolin $(10 \mu \mathrm{M}) / \mathrm{IBMX}(1 \mu \mathrm{M})(\mathrm{F} / \mathrm{I})$ on TXNIP level in INS-1 cells. (C, D and E) qRT-PCR shows the attenuation effect of 4-h GABA, GLP-1 or GLP-1 $1_{28-36}$ on HG-stimulated TxNIP level in INS-1 cells, WT and GLP-1 $R^{-1-}$ mouse islets. (F and G) LUC assay shows the attenuation effect of GABA or GLP-1 on TXNIP-LUC $(-1222$ to +47 and -208 to +47$)$ reporter activity in INS-1 cells cultured with HG. (H and I) qRT-PCR shows the attenuation effect of indicated reagent on HG-stimulated ChRebp expression in INS-1 cells $(\mathrm{H})$ and mouse islets (I). Panel A is a representative blot. For panel $\mathrm{B}, n=4$; for panels $\mathrm{C}$ to I, $n=3$. For qRT-PCR, cells were treated with indicated reagent (GABA, $50 \mu \mathrm{M} ; \mathrm{GLP}-1,10 \mathrm{nM} ; \mathrm{GLP}-1_{28-36}, 10 \mathrm{nM}$ ) in the absence of serum for $4 \mathrm{~h}$. For LUC assay, cells were transfected with indicated plasmid for $18 \mathrm{~h}$, following by indicated treatment for $4 \mathrm{~h}$ in the absence of serum. One-factor ANOVA was utilized for panels B-I. * and **, $P<0.05$ and 0.01 , respectively; values were compared to LG (5 mM) treatment. \# and \#\#, $P<0.05$ and 0.01 , respectively; values were compared to HG $(25 \mathrm{mM})$ cultured cells or islets in the absence of a treatment. Glu, glucose; GLPc, GLP-1 $1_{28-36}$.

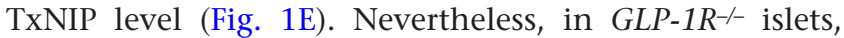
GABA treatment repressed TxNIP level about 1.7-fold (Fig. 1E), relatively weaker than that observed in WT islets (Fig. 1D, 2.4-fold).

Effect of GABA and GLP-1 on TxNIP promoter activity was then assessed. When the TxNIP-LUC fusion gene plasmid (-1224 TxNIP-LUC or -208 TxNIP-LUC) was transfected into INS-1 cells, HG treatment stimulated the LUC activity and the stimulation was attenuated by 4 -h treatment with GABA or GLP-1 (Fig. 1F and G). Furthermore, GABA, GLP-1, GLP-1 $1_{28-36}$, or forskolin/ IBMX treatment attenuated HG-induced ChREBP (Mlxipl) expression in INS-1 cells (Fig. 1H). Such repressive effect by GABA or GLP-1 treatment was also observed with HG-treated mouse islets (Fig. 1I).

(C) 2020 Society for Endocrinology Published by Bioscientifica Ltd. Printed in Great Britain

\section{GABA requires GLP-1R to effectively attenuate TxNIP protein level}

We then assessed the effect of GABA treatment on TxNIP protein levels in response to HG challenge. HG-stimulated TxNIP expression in INS-1 cells or mouse islets (Fig. $2 \mathrm{~A}$ and $\mathrm{B})$ can be attenuated by 4-h GABA, GLP-1, or GLP-1 ${ }_{28-36}$ treatment. Unexpectedly, in $G L P-1 R^{-/}$islets, GABA or GLP-1 did not reduce HG-stimulated TxNIP level (Fig. 2C). We also noticed that in $G L P-1 R^{-/-}$islets, 4-h HG treatment increased TxNIP level approximately 7-fold. In WT islets, the increase was about 2.5-fold (Fig. $2 \mathrm{~B}$ and $\mathrm{C}$ ). Thus, although GABA may repress TxNIP transcription via interacting with its own receptor/s in WT or $G L P-1 R^{-/}$islets cultured with $\mathrm{HG}$, it requires GLP-1R 
A INS-1

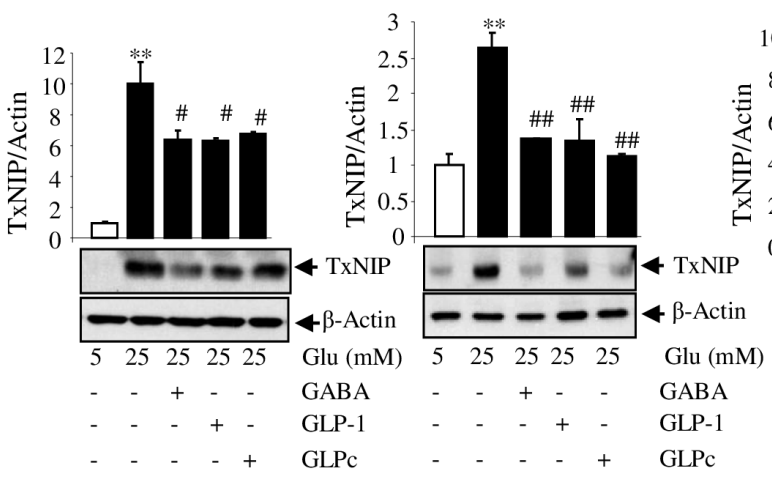

C $G L P-1 r^{\%}$ Islets

D INS-1

\section{E Heatmap}

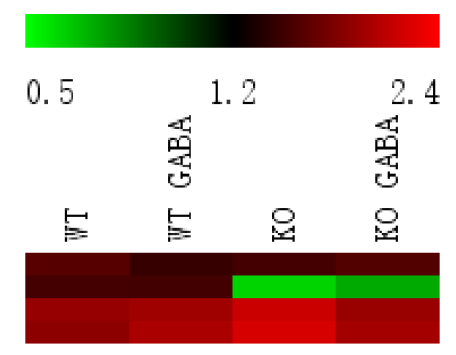

$\mathrm{F}$

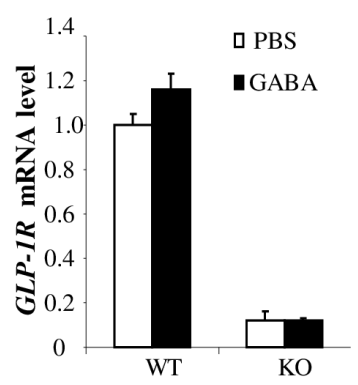

G TxNIP

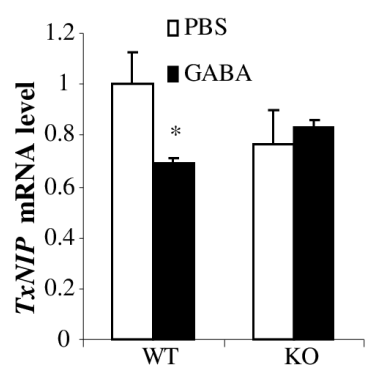

Figure 2

GABA requires GLP-1R to effectively attenuate TxNIP protein level. (A, B and C) Western blotting shows the attenuation effect of indicated treatment on HG-stimulated TxNIP expression in INS-1 cells (A), WT (B) and GLP-1R ${ }^{--}$(C) mouse islets. (D) Western blotting shows the blockage effect of MG132 (10 $\mu$ M) on GABA-mediated TxNIP level attenuation. (G) Heat-map shows the expression level of genes that encode TxNIP, GLP-1R, GIPR and ChREBP (MIxipl) in WT and GLP-1 $R^{-/-}$mouse islets with or without GABA treatment (50 $\mu \mathrm{M}$ for $4 \mathrm{~h}$ ). (F and G) GLP-1R and TxNIP levels in WT and GLP-1R-/- islets with or without 4-h GABA treatment, assessed by qRT-PCR. For panel A-D, F and G, $n=3$. One-factor ANOVA was utilized for panels A-D, while Student $t$-test was applied for panels $F$ and $G$. * and **, $P<0.05$ and 0.01 , respectively; values were compared to cell s received no treatment (panels $D$ and $G$ ) or LG treated cells (panels A, B and C). \# and \#\#, P<0.05 and 0.01, respectively; values were compared to HG treated cells (panels A, B and C) or GABA treatment (panel D). Ex, exendin-4; Glu, glucose; GLPc, GLP-1 28 -36; WT, wild type; KO, knockout. A full colour version of this figure is available at https://doi.org/10.1530/ JOE-20-0109.

to attenuate HG-stimulated TxNIP protein elevation efficiently. Whether this is partially due to a much

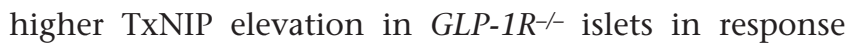
HG challenge remains to be determined. Furthermore, TxNIP attenuation by GABA treatment can be blocked by MG132, an inhibitor of proteasome degradation (Fig. 2D).

To initiate the assessment on GLP-1R-dependent regulation of pancreatic islet gene expression by GABA, we treated mouse islets from age matched male WT or $G L P-1 R^{-/}$mice with or without $4 \mathrm{~h}$ GABA treatment, followed by RNAseq analyses. For this set of initial study, mouse islets were treated with GABA in the absence of a HG challenge. Among 50,000+genes assessed, we picked those with Fragments Per Kilobase Million Mapped Reads $($ FPKM $)=$ or $>10$ in WT or GLP-1 $R^{-/-}$islets without GABA treatment for further analyses. By comparing these $8000+$ genes in WT and $G L P-1 R^{-/}$islets, we learned that GABA responsiveness was broadly altered (SUB5390909). We then assessed those that were up- or down-regulated by GABA for 1.5-fold or high. Only a small portion of genes that were up- or down-regulated by GABA in WT islets maintained their responsiveness to GABA treatment in $G L P-1 R^{-/}$islets (Supplementary Fig. 2 and Supplementary Table 3). Furthermore, in $G L P-1 R^{-/}$islets, numbers of genes that were up- or down-regulated by GABA increased 3.63 or 3.95 folds (Supplementary Fig. 3 and Supplementary Table 4). Supplementary Tables 5 and 6 listed genes that were activated or repressed by GABA in both WT and $G L P-1 R^{-/}$islets. As shown (Fig. 2E and Supplementary Table 7), GLP-1R 'mRNA signal' was eight times lower in GLP-1R ${ }^{-/-}$islets, while GABA treatment did not affect its level. We then found that TxNIP level in the absence of HG challenge was repressed by GABA for 1.4-fold in WT islets but not in $G L P-1 R^{-/-}$islets (Fig. 2E 
and Supplementary Table 7). Such GLP-1R-dependent repression, observed with the initial RNAseq screening, was then further verified by qRT-PCR in GABA-treated WT and $G L P-1 R^{-/-}$mouse islets (Fig. $2 \mathrm{~F}$ and G). Thus, in response to HG challenge, 4-h GABA treatment repressed TxNIP elevation 2.4-fold and 1.7-fold in WT islets and $G L P-1 R^{-/}$islets, respectively (Fig. 1D and E). Without HG challenge, GABA represses TxNIP modestly but in a GLP-1R-dependent manner.

\section{GLP-1R is required for GABA in attenuating STZ-induced 'diabetic syndromes'}

To evaluate the potential patho-physiological importance of GLP-1R-mediated GABA function, we then assessed the protective effect of GABA in a T1D mouse model. Male mice (GLP-1 $1 R^{-/-}$or WT littermates) were subject to first STZ injection. Two weeks later, second STZ injection was conducted, along with 13-week GABA administration in

A

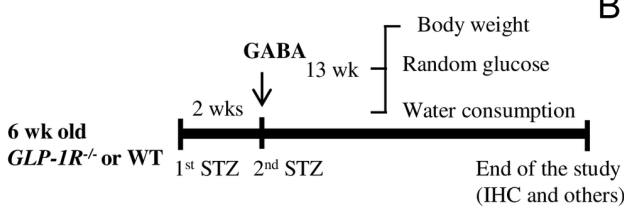

B mGLP-1R antibody
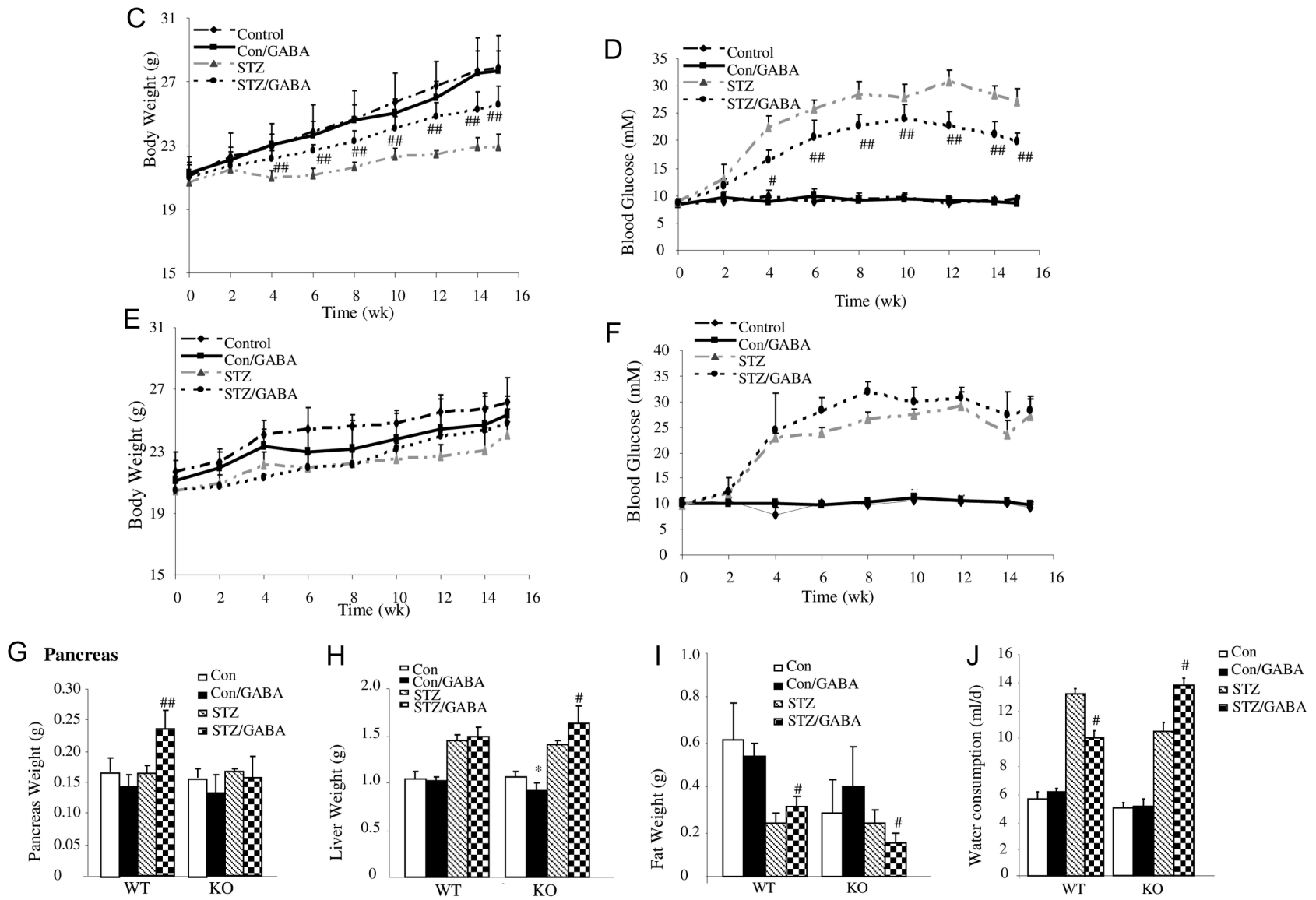

Figure 3

GLP-1R is required for GABA in attenuating 'diabetic syndromes' induced by STZ challenge- (A) A schematic illustration of the mouse experiments. (B) Detection of GLP-1R in WT and GLP-1R-/- mouse islets by immune staining. (C and D) Body weight and random glucose levels in control or STZ-challenged WT mice. (E and F) Body weight and random glucose levels in control or STZ-challenged GLP-1 $R^{-/-}$mice, with or without GABA administration. (H and I) Comparison of pancreas, liver and epididymal fat weight in WT and GLP-1 $R^{-/-}$mice with indicated treatment. () Daily water consumption in indicated group of mice. One-factor ANOVA was utilized for panels B-I. * or **, $P<0.05$ and 0.01 , respectively; values were compared to the control group (Con) for WT or GLP-1 $R^{-1-}$ mice. \# and \#\#, $P<0.05$ and 0.01, respectively; values were compared to the STZ group for WT or GLP-1 $R^{-1-}$ mice. $n=3$ for the two GLP-1 $R^{-1-}$ groups without STZ challenge, and $n=4$ or 5 for GLP-1 $R^{-1-}$ mice challenged with STZ, without and with GABA, respectively. $n=5$ for all the four WT groups. A full colour version of this figure is available at https://doi.org/10.1530/JOE-20-0109. 
the drinking water (Fig. 3A). Figure 3B shows the lack of GLP-1R signal in GLP-1R-/- mouse islets, assessed by immune histochemistry staining, utilizing a novel antimouse antibody (Jensen et al. 2018).

In WT mice along with the administration time, GABA treatment attenuated STZ-injection-induced bodyweight loss (Fig. 3C). Furthermore, GABA administration moderately but significantly attenuated STZ-injectioninduced random blood glucose elevation, although euglycemia was not reached (Fig. 3D). In WT mice without STZ injection, no appreciable effects on bodyweight change or random glucose levels with GABA administration were observed (Fig. 3C and D). Importantly, the previously mentioned effects ware virtually absent in $G L P-1 R^{-/}$mice which received the same STZ challenge and GABA administration (Fig. 3E and F).

Figure 3G shows that, in WT mice but not in GLP-1 $R^{-/-}$ mice with STZ challenge, GABA administration increased the weight of pancreas. In both WT and $G L P-1 R^{-/}$mice, STZ challenge increased liver weight, which was not affected by GABA administration in WT mice (Fig. 3H). In $G L P-1 R^{-/}$mice, GABA administration reduced liver weight without STZ challenge but increased liver weight in the presence of STZ challenge (Fig. 3H). Furthermore, in WT mice, STZ challenge reduced epididymal fat weight, while GABA administration partially attenuated the fat loss (Fig. 3I). This effect of GABA, however, was absent

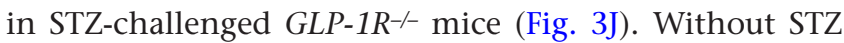
challenge, GABA administration generated no appreciable

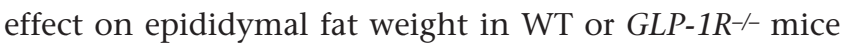
(Fig. 3I). Finally, GABA administration reduced daily water consumption in STZ-challenged WT mice but not in $G L P-1 R^{-/-}$mice (Fig. 3J). These observations collectively suggest that GLP-1R is required for GABA to exert its attenuation effects on 'diabetic syndromes' generated with STZ challenge, although the attenuation effects observed in our current experimental settings were relatively modest.

\section{Upon STZ challenge, GABA administration increases $\beta$-cell mass in WT but not GLP-1 $R^{-/-}$mice}

We then assessed $\beta$-cell and $\alpha$-cell mass in those eight groups of mice. Without STZ challenge, GABA administration generated no appreciable effect on $\beta$-cell mass in WT mice (Fig. 4A and B). With STZ challenge, GABA administration increased $\beta$-cell mass moderately but significantly (Fig. 4B). For WT mice, $\alpha$-cell mass was not affected by GABA treatment regardless of STZ challenge (Fig. 4C). In WT mice, STZ challenge reduced numbers of small-sized
(0-50 $\mu \mathrm{M})$, medium-sized $(50-100 \mu \mathrm{M})$, large sized $(100-200 \mu \mathrm{M})$ and extra-large-sized $(>200 \mu \mathrm{M})$ pancreatic islets, while GABA treatment efficiently increased smalland extra-large-sized islet numbers (Fig. 4D). Without STZ challenge, GABA treatment also increased the number of extra-large-sized islets (Fig. 4D). We also observed reduced Pax6 ${ }^{+} \beta$-cell number following STZ challenge, while GABA administration generated no reverse effect (Fig. 4E and F).

In $G L P-1 R^{-/-}$mice, GABA administration had no effect on reversing STZ-challenge induced $\beta$-cell loss (Fig. $4 \mathrm{G}$ and $\mathrm{H})$. Again, we did not see appreciable changes on $\alpha$-cell mass, regardless of STZ challenge or GABA administration (Fig. 4I). With STZ challenge, we only observed small trends of number increase on small-sized and mediumsized islets upon GABA administration (Fig. 4J). Finally, in $G L P$ - $1 R^{-/-}$mice, STZ challenge reduced Pax $6^{+} \beta$-cell, and the reduction cannot be reversed by GABA administration (Fig. 4L). It is worth to mention that cytoplasmic Pax6 signal was observed in the four groups of mice which received STZ challenge, in the absence and presence of GABA treatment (Fig. 4E and K), which could be due to non-specific staining.

\section{Restoration effects of GABA on $\beta$-cell Pdx1 or Nkx6.1 expression and Ki67 incorporation are observed in STZ-challenged WT mice but not in GLP-1 $R^{-/-}$mice}

In pace with the attenuation of $\beta$-cell loss by GABA in STZchallenged WT mice, GABA administration also increased Pdx $1^{+}$, Nkx6.1+, and Ki67+ $\beta$-cells (Fig. 5A, B, C, D, E and F). Such effects were absent in WT or $G L P-1 R^{-/}$mice without STZ challenge. In STZ-challenged $G L P-1 R^{-/-}$mice, GABA administration generated no effect on $\beta$-cell Pdx1 or Nkx6.1 expression, or Ki67 incorporation (Fig. 5G, H, I, $\mathrm{J}, \mathrm{K}$ and $\mathrm{L}$ ). We then assessed the RNAseq data. Four-hour GABA treatment in the absence of HG challenge had no profound effect on a battery of islet specific genes in WT or GLP-1 $R^{-/-}$islets, including $P d x 1, N k x 6.1, I s l 1$, Mafa and the three TCF members. However, basal Isl1, Pdx1, Mafa, Nkx6.1, Glu2, but not Pax6, levels were lower in GLP-1 $R^{-/}$ islets (Supplementary Table 8).

\section{TxNIP knockdown increases GLP-1R expression and GABA or GLP-1 responsiveness in INS-1 cells}

To explore mechanisms underlying GLP-1R-dependent function of GABA in pancreatic $\beta$-cells, we then ask whether GABA treatment increases GLP-1R expression. As presented in Fig. 2E and F, in the absence of HG challenge, 4-h GABA treatment did not stimulate GLP-1R expression 


\begin{tabular}{l|l|l|l|l|}
$\begin{array}{l}\text { Journal of } \\
\text { Endocrinology }\end{array}$ & W Shao et al. & $\begin{array}{l}\text { GLP-R mediated pancreatic } \\
\text { function of GABA }\end{array}$ & $246: 3$ & 215 \\
\hline
\end{tabular}

A
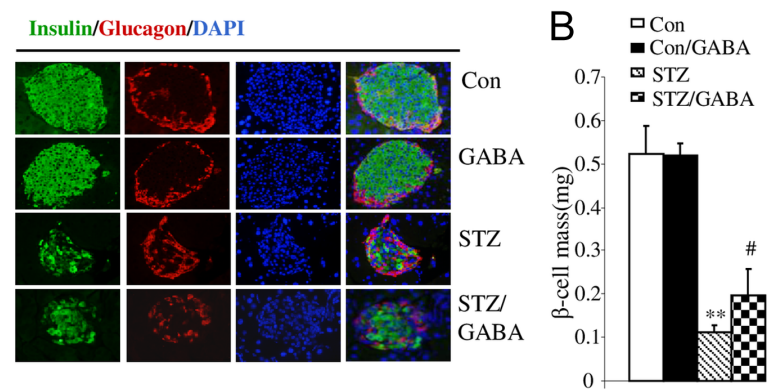

E

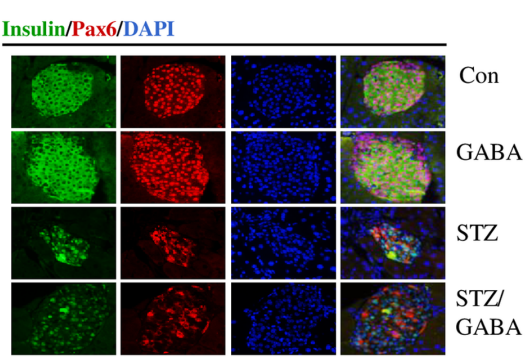

F

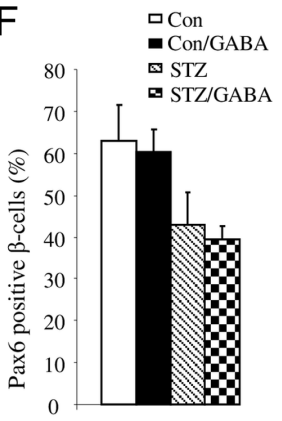

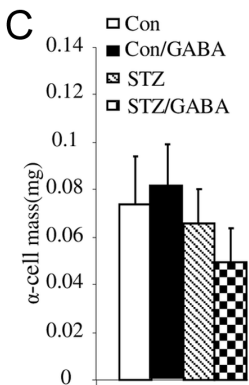

D

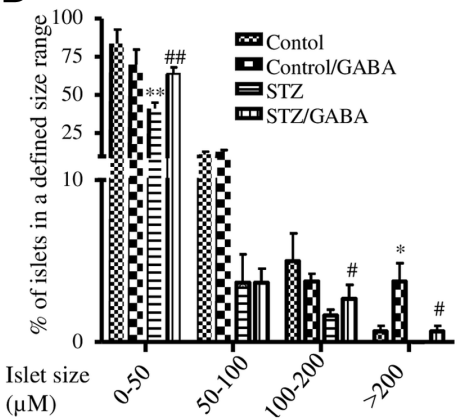

G

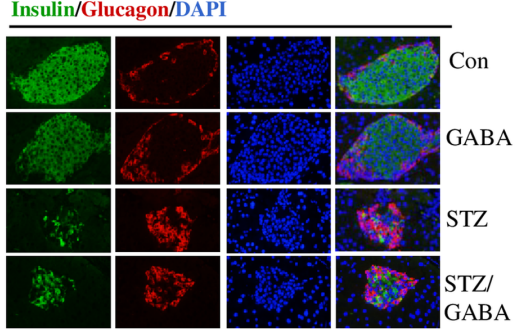

$\mathrm{H}$



I

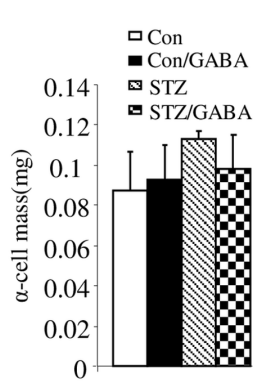

$\mathrm{J}$

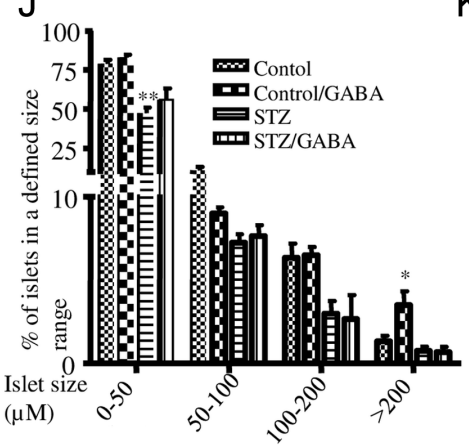

K

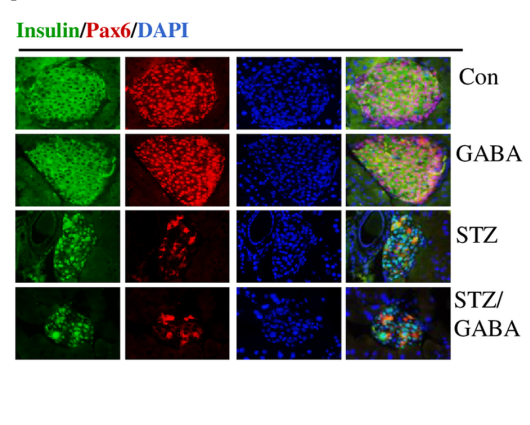

L

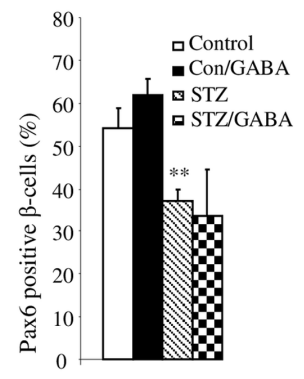

\section{Figure 4}

Upon STZ challenge, GABA administration increases $\beta$-cell mass in WT mice but not in GLP-1 $R^{-/-}$mice. (A, B and C) Insulin and glucagon staining (A), $\beta$-cell mass (B) and $\alpha$-cell mass (C) in indicated four groups of WT mice. (D) Comparison of numbers of different sized pancreatic islets in each of the four groups of WT mice. (E and F) Insulin and Pax6 staining (E) and comparison of Pax $6^{+} \beta$-cells (F) in the four groups of WT mice. (G, $H$ and I) Insulin and glucagon staining $(\mathrm{G}), \beta$-cell mass $(\mathrm{H})$ and $\alpha$-cell mass $(\mathrm{I})$ in indicated four groups of $G L P$ - $1 R^{-/-}$mice. (J) Comparison of numbers of different sized mouse

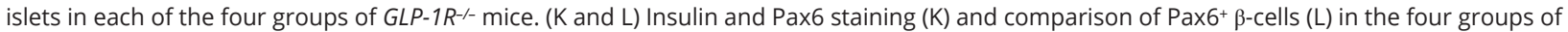
$G L P-1 R^{-/-}$mice. One-factor ANOVA was utilized for panels B-D, F, H-J and L. * or **, values were compared to the control group (Con). \# and \#\#, $P<0.05$ and 0.01, respectively; values were compared to the STZ group. $n=3$ for the two $G L P-1 R^{-/-}$groups without STZ challenge, and $n=4$ or 5 for GLP-1 $R^{-/-}$mice challenged with STZ, without and with GABA, respectively. $n=5$ for all the four WT groups. DAPI, 4',6-diamidine-2'-phenylindole dihydrochloride. A full colour version of this figure is available at https://doi.org/10.1530/JOE-20-0109.

in mouse islets. We then found that, in the presence of HG challenge in INS-1 cells, 4- or 24-h GABA treatment also did not increase GLP-1R level (Fig. 6A). Recent studies have suggested that TxNIP stimulates miR-204, which in turn represses GLP-1R expression (Xu et al. 2013, Jo et al. 2018). We hence utilized siRNA mediated knockdown in INS-1 cells, assessing the effect of TxNIP knockdown on GABA and GLP-1 responsiveness. We found that the utilization of the two TxNIP siRNAs (48 h) significantly reduced TxNIP protein (Fig. 6B) and TxNIP mRNA (Fig. 6C) levels. Fig. 6D shows that $48 \mathrm{~h}$ after the utilization of TxNIP siRNA1, GLP-1R level increased more than 2.5-fold, associated with elevated expression of the three pancreatic $\beta$-cell specific genes, including $P d x 1, N k x 6.1$ and Mafa. Finally, we assessed whether, following TxNIP knockdown, INS-1 cells show increased responsiveness to GABA or GLP-1 treatment on insulin secretion. As shown, $48 \mathrm{~h}$ following siRNA mediated TxNIP knockdown, INS-1 cells exhibited 
A

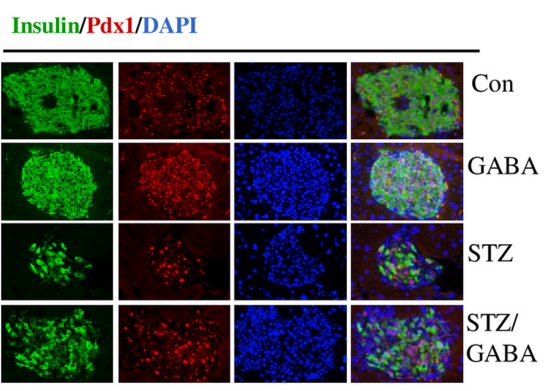

E

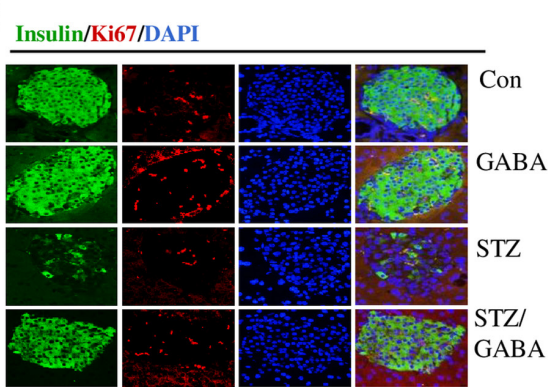

I

Insulin/Nkx6.1/DAPI

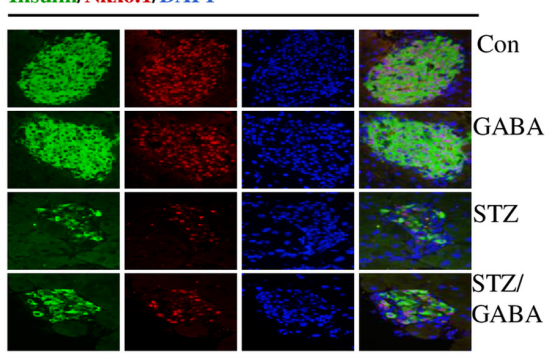

B

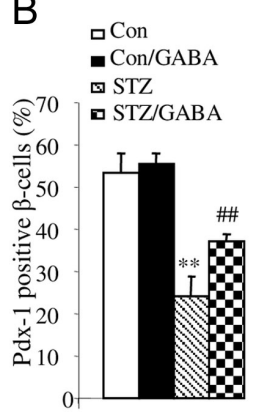

F
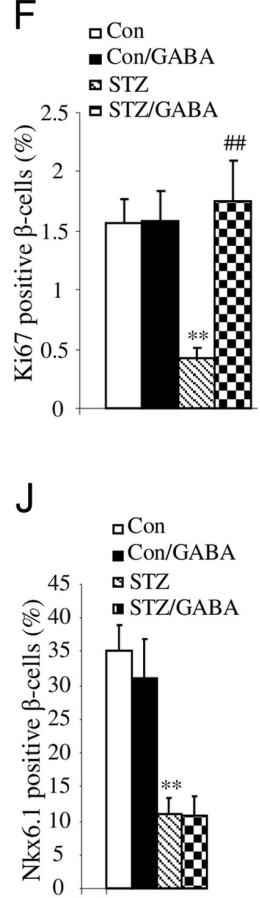

C

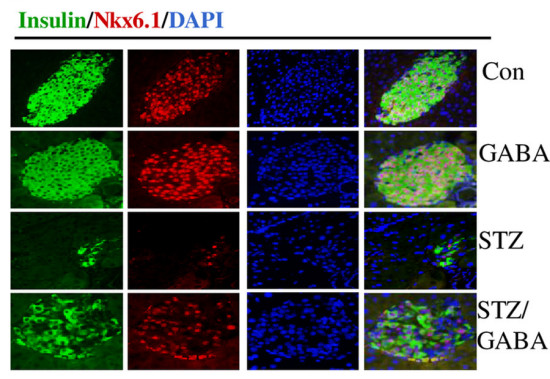

G

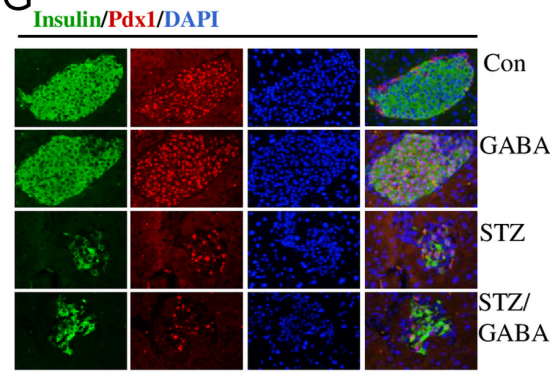

K

Insulin/Ki67/DAPI

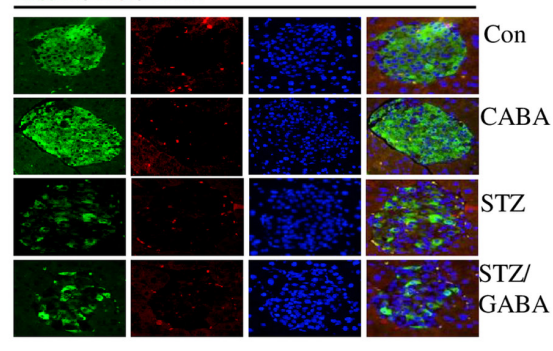

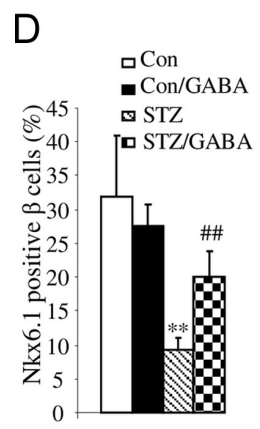

$\mathrm{H}$

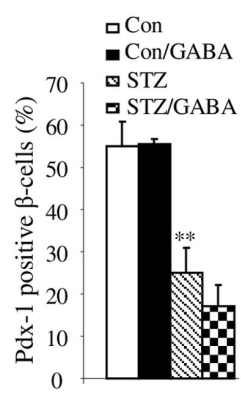

L



Figure 5

Effects of GABA administration on stimulating $\beta$-cell Pdx1 or Nkx6.1 expression and Ki67 incorporation are absent in GLP-1 $1 R^{-/-}$mice upon STZ challenge$(A, B, C, D, E$ and F) Immunohistochemistry detection (,$C$ and $E)$ and quantification (B, D and F) of $\mathrm{Pdx} 1^{+}(A$ and $B), N_{k x 6.1^{+}}(C$ and $D)$ and Ki67 $(E$ and F) insulin-producing cells in each of the four groups of WT mice. $G-L)$ Immunohistochemistry detection $(G, I$ and $K)$ and quantification $(H, J$ and $L)$ of $P d x 1^{+}(G$

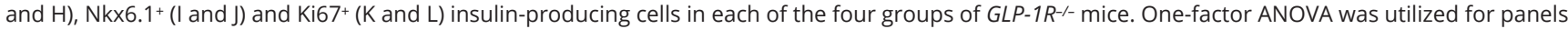
$B, D, F, H, J$ and $L$. **, $P<0.01$, values were compared with the control group. \#\#, $P<0.01$, values were compared with the STZ group. $n=3$ for the two $G L P-1 R^{-/-}$groups without STZ challenge, and $n=4$ or 5 for GLP-1R-/- mice challenged with STZ, without and with GABA, respectively. $n=5$ for all the four WT groups. A full colour version of this figure is available at https://doi.org/10.1530/JOE-20-0109.

elevated response to $\mathrm{HG} / \mathrm{GABA}$ treatment on insulin secretion (Fig. 6E). The cells also showed elevated response to HG/GLP-1-stimulated insulin secretion (Fig. 6F).

\section{GABA exerts its effects on stress protection and stimulates the CAMP- $\beta$-cat signalling}

We then further assessed stress protective effects of GABA with the in vitro tools. In addition to HG, $\beta$-cell TxNIP level can also be induced by glucocorticoid treatment (Reich et al. 2012).

$\begin{array}{lr}\text { https://joe.bioscientifica.com } & \text { (C) } 2020 \text { Society for Endocrinology } \\ \text { https://doi.org/10.1530/JOE-20-0109 } & \text { Published by Bioscientifica Ltd. }\end{array}$

We hence assessed the effect of GABA treatment on preventing cleaved-caspase 3 accumulation in response to HG, dexamethasone (DEX), or STZ treatment. DEX or STZ treatment was found to induce TxNIP level in INS-1 cells cultured with LG (Supplementary Fig. 3), while GLP-1 or GABA treatment reduced active caspase 3 levels in INS-1 cells treated with HG (Fig. 7A) or DEX in the absence of HG challenge (Fig. 7B). Furthermore, STZ-treatmentinduced active caspase 3 expression was also attenuated by GABA treatment (Fig. 7C).

GABA has been shown to activate CREB in neuronal cells, while cAMP-CREB is a central pathway in 
$\mathrm{A}_{1.4}$ 口Con

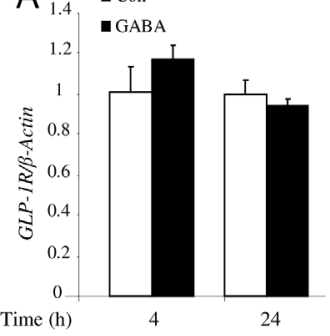

B

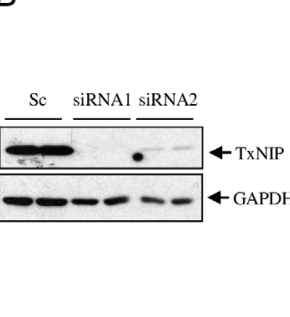

C

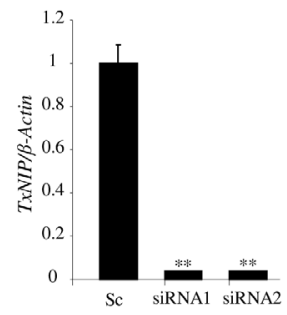

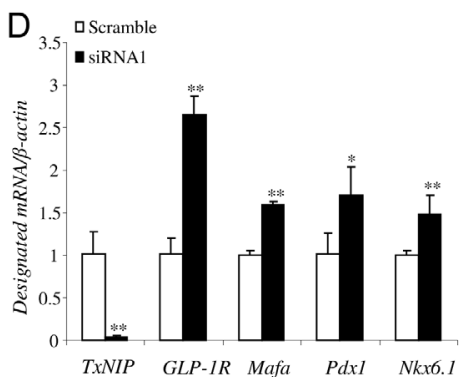

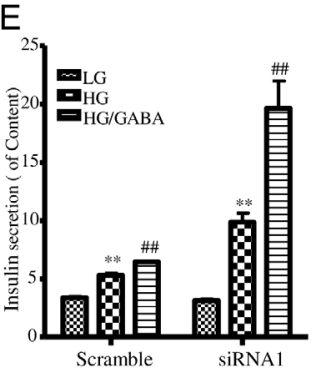

F

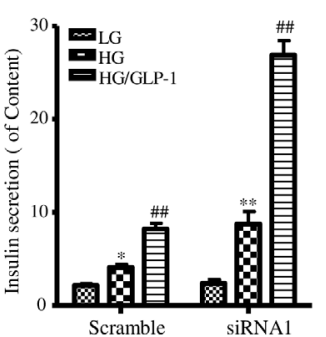

\section{Figure 6}

TXNIP knockdown increases GLP-1R level and GLP-1 responsiveness in INS-1 cells- (A) qRT-PCR shows the detection of GLP-1R cultured in medium with $25 \mathrm{mM}$ glucose, with or without GABA $(50 \mu \mathrm{M})$ treatment for indicated time. (B and C) Detection of TxNIP expression by Western blotting (B) or qRT-PCR (C) following siRNA-mediated TxNIP knockdown for $48 \mathrm{~h}$. (D) qRT-PCR shows the detection of indicated $\beta$-cell specific gene expression in INS-1 cells following TxNIP knockdown. (E-F) Assessment of TxNIP knockdown on glucose (LG vs HG) or HG plus GABA $(50 \mu \mathrm{M})(\mathrm{E})$ or HG plus GLP-1 (10 nM) (F) induced insulin secretion in INS-1 cells. Student $t$-test was applied for panels $A, C$ and $D$, while One-factor ANOVA was utilized for panels $E$ and $F$. For panels A, C-F, $n=/>3$. * and **, $P<0.05$ and 0.01 , respectively; values were compared to scrambled siRNA (Sc) treated cells (panels C and D) or to cells treated with LG (panels E and F). $\# \#, P<0.01$, values were compared to HG treated samples (panels E and F). Sc, scrambled siRNA.

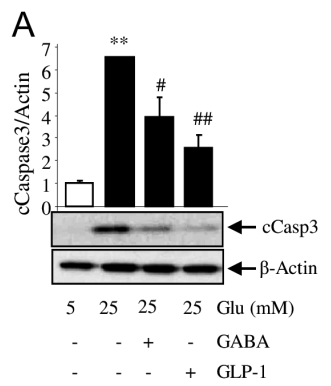

F. Islets
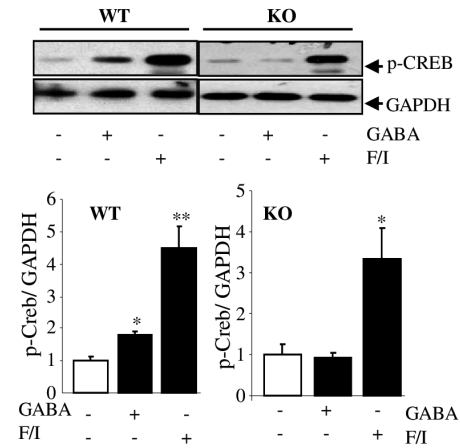
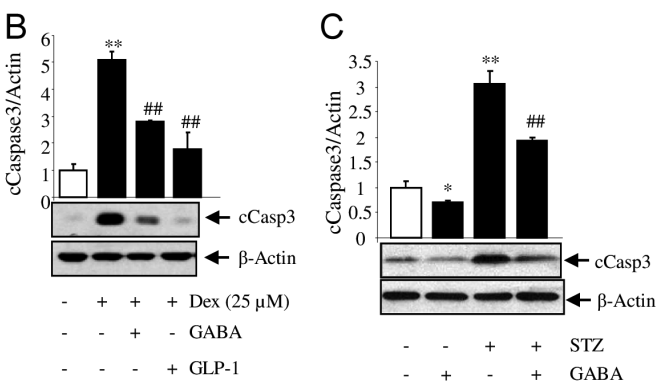

G Islets

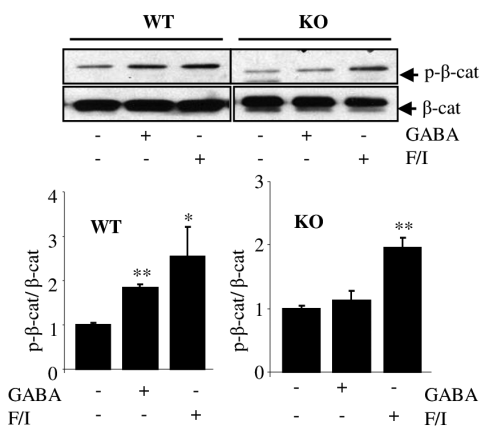

D INS-1

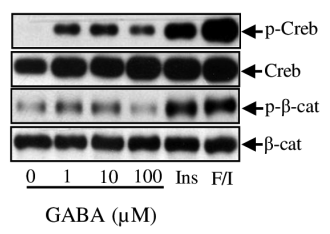

$\mathrm{E}$

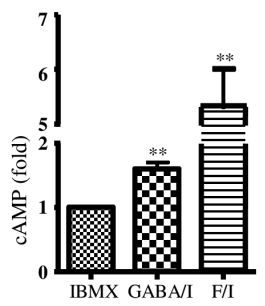

$\mathrm{H}$

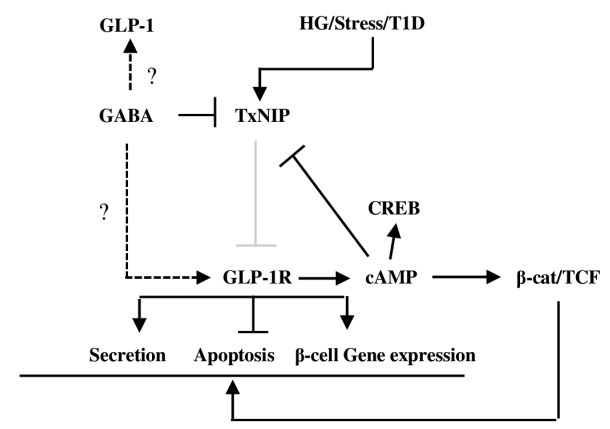

Figure 7

GABA exerts its effects on stress protection in $\beta$-cells and it stimulates cAMP- $\beta$-cat signaling cascade- (A, B and C) Western blotting show cleaved-caspase 3 (cCasp3) levels in INS-1 cells challenged with HG ( $25 \mathrm{mM})$, Dex (dexamethasone, $25 \mu \mathrm{M})$ or STZ (1 mM), along with an indicated treatment for 4 h. (D) Effect of 30-min GABA treatment (with indicated dose) on CREB (S133) and $\beta$-cat (S675) phosphorylation in INS-1 cells. Insulin (Ins, 100 nM) and F/I (10 $\mu$ M forskolin and $1 \mu \mathrm{M}$ IBMX) served as positive controls. (E) Effect of 30-min GABA (50 $\mu \mathrm{M})$ treatment on cellular cAMP levels in INS-1 cells, with F/I as the positive control. (F and G) Effect of GABA treatment on CREB (S133) (F) and $\beta$-cat (S675) (G) phosphorylation in WT or GLP-1 ${ }^{-1-}$ mouse islets. F/I served as the positive control. Due to technical problems, for panel F, the house keeping protein utilized for normalization was GAPDH instead of total CREB. For panel G, duplicated blots were run each time against total $\beta$-cat and $\beta$-cat (S675), respectively. (H) A diagram shows our current understanding on GLP-1R-mediated GABA function. Student $t$-test was applied for panels E, F and G, while One-factor ANOVA was utilized for panels A-C. For panels A-C and $\mathrm{E}-\mathrm{G}, n=$ or $>3$ for each given treatment. * or **, $P<0.05$ and 0.01 , respectively; values were compared to LG treatment (panel A) or vehicle treatment (panels B, C, E, F and G). \#\#, $P<0.01$, values were compared to HG treatment (panel A), Dex treatment (panel B), STZ treatment (panel C). Question marks in panel $\mathrm{H}$ with dotted lines indicate yet to be further assessed pathways. 
hippocampal neurogenesis (Jagasia et al. 2009). In INS-1 cells, we found that CREB S133 phosphorylation can also be stimulated by GABA treatment (Fig. 7D). We also observed that treating INS-1 cells with 1 or $10 \mu \mathrm{M}$ GABA increased $\beta$-cat S675 phosphorylation (Fig. 7D). To determine the involvement of cAMP signaling, we treated INS-1 cells with GABA (forskolin as the positive control). As shown, GABA treatment increased cellular cAMP levels (Fig. 7E). We then assessed the effect of GABA on mouse islets CREB and $\beta$-cat phosphorylation. GABA treatment increased both CREB and $\beta$-cat phosphorylation in WT mouse islets but not in $G L P-1 R^{-/-}$mouse islets (Fig. $7 \mathrm{~F}$ and $\mathrm{G}$ ).

\section{Discussion}

Besides central and peripheral nervous systems, GABA is produced in peripheral tissues including lung and pancreatic islets (Xiang et al. 2007, Soltani et al. 2011, Purwana et al. 2014, Januzi et al. 2018). GABA was shown to inhibit glucagon secretion (Rorsman et al. 1989, Xu et al. 2006). During the past few years, protective and potential regenerative effect of GABA on pancreatic $\beta$-cells were intensively studied, including the effect on implanted human $\beta$-cells in mice (Tian et al. 2013). Ben-Othman et al. reported that long-term GABA administration in mice induced $\alpha$-cell mediated $\beta$-like cell neogenesis (Ben-Othman et al. 2017), while Li et al. showed that the antimalarial drug artemisinins functionally represses the transcription factor Arx, leading to the transdifferentiation of $\alpha$-cells to functional $\beta$-like cells. ( $\mathrm{Li}$ et al. 2017). Two most recent studies, however, denied the observation of such trans-differentiation (Januzi et al. 2018, van der Meulen et al. 2018). The discrepancy could be due to experimental settings, methods for GABA administration of dosages of GABA utilized.

With current experimental settings, we did not observe the effect of STZ or GABA on $\alpha$-cell mass or a clue for the existence of $\alpha$-cells to functional $\beta$-like cells trans-differentiation. We, however, did observe in STZchallenged mice the effect of GABA on attenuating 'diabetic syndromes' and improving glucose disposal, associated with increased $\beta$-cell mass, $\beta$-cell Pdx 1 or Nkx6.1 expression, and Ki67 incorporation. Our observations support the view on $\beta$-cell protective and potential regenerative effect of GABA (Purwana et al. 2014, Feng et al. 2017). Importantly, we show here a novel function of GABA, inhibition of TxNIP, and that this function is shared by GLP-1. This function of GABA, as well as its potential $\beta$-cell neogenesis function, at least partially relies on GLP-1R.
TxNIP inhibits thioredoxin and thereby modulates the cellular redox status and induces oxidative stress (Shalev 2014). TxNIP deficient mice show increased $\beta$-cell mass and are protected against multiple low-dose STZ challenge (Chen et al. 2008, Masson et al. 2009). Early investigations demonstrated that GLP-1 based drug reduces TxNIP protein level in pancreatic $\beta$-cells, involving cAMP signaling activation and proteasome-mediated TxNIP degradation (Chen et al. 2006, 2008, Shao et al. 2010). We show here that cAMP promoting agents forskolin/ IBMX also attenuated HG-induced $\beta$-cell TxNIP mRNA expression and TxNIP promoter activity and that this feature is shared by GABA and GLP-1. It is notable that, in response to $\mathrm{HG}$ challenge, the attenuation effect of GABA in $G L P-1 R^{-/}$islets was attenuated when compared with that in WT islets (1.7 fold vs 2.4 fold, Fig. 1D and E). In the absence of HG challenge, however, the attenuation effect of GABA on TxNIP level was modest (1.4 fold) but it is GLP-1R dependent (Fig. 2G). Furthermore, the attenuation effect of GABA or GLP-1 on HG-induced TxNIP expression was associated with their attenuation on ChREBP, a TXNIP transcriptional activator (Cha-Molstad et al. 2009). Importantly, our observations suggest that, although GABA can repress TxNIP expression in WT or GLP-1R-/islets at mRNA level, it requires GLP-1R to effectively attenuate elevated TxNIP protein levels in response to HG challenge. We have demonstrated previously that GLP-1 treatment leads to proteasome-mediated TxNIP degradation (Shao et al. 2010). We show here that GABAmediated TxNIP reduction in response to HG challenge can also be blocked by MG132. Detailed involvement of GLP-1R on GABA-mediated TxNIP protein degradation requires further investigation. One can speculate that GLP-1R is involved in mediating the repressive effect of GABA on TxNIP mRNA transcription and proteasomemediated TxNIP degradation.

GABA can be administrated by i.p. injection (Soltani et al. 2011, Ben-Othman et al. 2017, Feng et al. 2017, Ackermann et al. 2018) or oral intake (Purwana et al. 2014, Liu et al. 2017). We took the second option to avoid potential long-term injection-induced side effects. In our previous investigations, this approach allowed us to show the effect of GABA on increasing grafted human $\beta$-cell proliferation (Purwana et al. 2014), as well as potential combined effect of GABA and sitagliptin on $\beta$-cell regeneration (Liu et al. 2017). In the current experimental settings, each mouse would take $24 \mu \mathrm{g}$ GABA daily, although diabetic mice would take more. The variation will not prevent us from claiming the GLP-1R-dependent beneficial effects of GABA, as in diabetic GLP-1 $1 R^{-/}$mice, 
even though more GABA would be consumed, defects were not corrected. In addition, STZ injection itself may lead to increased $\alpha$-cell mass and subsequently $\beta$-cell regeneration for compensation. We have, nevertheless, included the control groups without STZ injection, with and without GABA for both WT and GLP-1 $R^{--}$mice. Furthermore, we have modified the STZ-injection protocol, utilizing a subdosage of STZ in this study, which itself, did not affect $\alpha$-cell mass (Fig. 4C and I). In GLP-1-/- mice, STZ treatment significantly reduced Pax6 ${ }^{+}$insulin producing cell number, which cannot be restored with GABA treatment (Fig. 4L). Together, we did not obtain the evidence or the clue that leads to the suggestion that GABA treatment triggers a $\alpha$-cell to $\beta$-cell trans-differentiation.

In the current study, although we observed beneficial effects of GABA administration in WT mice with STZ challenge, euglycemia was not reached. In addition, other beneficial effects including the increase on $\beta$-cell mass, $\beta$-cell Pdx1 or Nkx6.1 expression were relatively modest. Nevertheless, the long-term GABA administration in current study did increase $\beta$-cell Ki67 incorporation robustly in WT mice with STZ challenge. Importantly, these effects were virtually absent in $G L P-1 R^{-/}$mice. Furthermore, in both WT and $G L P-1 R^{-/-}$mice without STZ challenge, the effect of GABA administration was marginal if not none. In WT mouse islets without HG challenge, 4-h GABA treatment generated no or marginal effect on a battery of $\beta$-cell specific genes, although the treatment reduced TxNIP level. These observations suggest that GABA may only exert its pathophysiological function effectively in pancreatic islets when they are attacked by HG or other deleterious factors. Indeed, we observed in the current study that GABA treatment reduced cleavedcaspase 3 levels in INS- 1 cells challenged by HG, STZ, or dexamethasone. Furthermore, in vivo effect of long-term GABA administration on $\beta$-cell gene expression in the presence and absence of GLP-1R will not be the same as the 4-h in vitro treatment, which needs to be assessed further with expanded RNAseq (including HG challenge and additional treatment time) and related approaches.

Wnt signaling pathway is evidently involved in pancreatic $\beta$-cell genesis and proliferation, glucosestimulated insulin secretion, and the production and function of incretin hormones (Fujino et al. 2003, Yi et al. 2005, Liu \& Habener 2008, Garcia-Martinez et al. 2009, Jin 2016). $\beta$-Cat forms the bipartite transcription factor $\beta$-cat/TCF with a TCF family member, including TCF7L2 (Grant et al. 2006, Zhou et al. 2014). GLP-1 stimulates $\beta$-cell activity (Liu \& Habener 2008), while $\beta$-cat/TCF functional knockdown attenuates GLP-1R and GIPr expression (Shao et al. 2015), suggesting that $\beta$-cat/TCF and GLP-1/GLP-1R form the positive feedback loop. The recognition of GLP-1R-mediated GABA function in pancreatic islets and pancreatic $\beta$-cells also further expands our view on metabolic functions of the developmental Wnt signaling pathway effector during adulthood (Jin 2016).

PKA-mediated $\quad \beta$-cat S675 phosphorylation was initially reported by Hino et al. (2005). Such phosphorylation was then demonstrated in various cell lineages by GLP-1, insulin, and IGF-1, involving other protein kinases such as p21 activated protein kinases (PAKs) (Chiang \& Jin 2014). We show here that $\beta$-cat S675 phosphorylation can also be stimulated by GABA, dependent on GLP-1R, raising a question whether this is mediated by $G_{A B A}$ receptor $\left(G_{A B A} R\right)$, on which less attention has been made by diabetes researchers. $\mathrm{GABA}_{B} \mathrm{R}$, like GLP-1R, is a member of G-protein coupled receptor (GPCR). A previous study showed that GABA can activate CREB, which is a central pathway in hippocampal neurogenesis (Jagasia et al. 2009).

Further mechanistic exploration on GLP-1Rdependent pancreatic function of GABA is desired. It remains to be assessed whether GLP-1R physically interacts with a GABA receptor, especially $\mathrm{GABA}_{B} \mathrm{R}$, which is a GPCR, and its able to activate the CREB/PKA signaling cascade (Jagasia et al. 2009). Alternately, GABA may exert its function via an interaction with GLP-1R directly. The lack of reliable GLP-1R antibodies (Panjwani et al. 2013, Baggio et al. 2018) makes this test currently difficult. It also remains to be tested whether GABA administration temporally and spatially affects endogenous GLP-1 or GLP-1R levels, or GLP-1 sensitivity. Here we started our mechanistic exploration, asking whether GABA treatment increases GLP-1 responsiveness via elevating $G L P-1 R$ level or via other means. Utilizing the INS-1 cell model, although we did not obtain direct evidence that $G L P-1 R$ level can be directly stimulated by GABA in our experimental settings, we did find that attenuation of TxNIP level is a common feature shared by GABA and GLP-1 and that TxNIP knockdown leads to increased $G L P-1 R$ level and increased GLP-1R responsiveness. These observations are in agreement with recent observations made by Jo and colleagues that TxNIP negatively regulates GLP-1R and a few $\beta$-cell specific genes (Jo et al. 2018).

Figure 7H shows our current view on GLP-1R-mediated GABA function in pancreatic $\beta$-cells. TxNIP level is elevated in response to HG or other stress challenges and in T1D subjects (Jo et al. 2018). GABA shares a common feature with GLP-1 in reducing TxNIP, and at least the reduction 
at the TxNIP protein level in response to HG challenge requires GLP-1R. This is likely due to cAMP/ $\beta$-cat signaling activation, with the participation of GLP-1R. It has been shown that TxNIP elevation or diabetes is accompanied with increased level of miR-204, which represses GLP-1R (Jo et al. 2018), leading to down-regulated expression of Mafa and other $\beta$-cell specific genes. In the current study, increased GLP-1R level cannot be detected by direct GABA treatment in the INS-1 cell line. Thus, the proposed TxNIPmiR-204-GLP-1R signaling network by Jo and colleagues (Jo et al. 2018) cannot be simply inactivated by a rapid TxNIP reduction with GABA or GLP-1 treatment.

In summary, the current study reveals that TxNIP is a common target of GABA and GLP-1 based drugs. We also suggest that the pancreatic GLP-1R-cAMP- $\beta$-cat signaling cascade also mediates the physiological function of GABA as well as the potential 'pharmacological' effect of GABA administration. Whether this is mediated by the crosstalk between GLP-1R and $\mathrm{GABA}_{\mathrm{B}} \mathrm{R}$, a GPCR in nature, deserves further investigations. Although, in our current experimental settings, the in vivo beneficial effect of GABA administration did not make the 'diabetic' mice reach euglycemia and $\beta$-cell mass was only partially restored, we revealed the existence of GLP-1R-dependent pancreatic function of GABA. These observations provide a clear rationale for developing combined therapy with GABA and GLP-1-based drugs in T1D and its complications.

\section{Supplementary materials}

This is linked to the online version of the paper at https://doi.org/10.1530/ JOE-20-0109.

\section{Declaration of interest}

The authors declare that there is no conflict of interest that could be perceived as prejudicing the impartiality of the research reported.

\section{Funding}

This study was supported by an Operating grant from the Juvenile Diabetes Research Foundation (JDRF, 2-SRA-2015-64) to Q W, G P, and TJ and a pilot grant from Banting and Best Diabetes Centre (BBDC) to T J.

\section{Author contribution statement}

W J, W L, Z S, O I conducted the bench work. L P and Z S did the analysis of RNAseq data. G J P, Q W and T J designed the project and obtained the funding support. TJ is the lead author of the manuscript.

\section{Acknowledgements}

The authors thank Dr Daniel Drucker for providing the GLP-1R-1- mice and Dr Anath Shalev for the original human TXNIP promoter construct.

\section{References}

Ackermann AM, Moss NG \& Kaestner KH 2018 GABA and artesunate do not induce pancreatic alpha-to-beta cell transdifferentiation in vivo. Cell Metabolism 28 787.e783-792.e783. (https://doi.org/10.1016/j. cmet.2018.07.002)

Baggio LL, Yusta B, Mulvihill EE, Cao X, Streutker CJ, Butany J, Cappola TP, Margulies KB \& Drucker DJ 2018 GLP-1 receptor expression within the human heart. Endocrinology 159 1570-1584. (https://doi.org/10.1210/en.2018-00004)

Ben-Othman N, Vieira A, Courtney M, Record F, Gjernes E, Avolio F, Hadzic B, Druelle N, Napolitano T, Navarro-Sanz S, et al. 2017 Longterm GABA administration induces alpha cell-mediated beta-like cell neogenesis. Cell 168 73.e11-85.e11. (https://doi.org/10.1016/j. cell.2016.11.002)

Cha-Molstad H, Saxena G, Chen J \& Shalev A 2009 Glucose-stimulated expression of Txnip is mediated by carbohydrate response elementbinding protein, $\mathrm{p} 300$, and histone $\mathrm{H} 4$ acetylation in pancreatic beta cells. Journal of Biological Chemistry 284 16898-16905. (https://doi. org/10.1074/jbc.M109.010504)

Chen J, Couto FM, Minn AH \& Shalev A 2006 Exenatide inhibits beta-cell apoptosis by decreasing thioredoxin-interacting protein. Biochemical and Biophysical Research Communications 346 1067-1074. (https://doi. org/10.1016/j.bbrc.2006.06.027)

Chen J, Hui ST, Couto FM, Mungrue IN, Davis DB, Attie AD, Lusis AJ, Davis RA \& Shalev A 2008 Thioredoxin-interacting protein deficiency induces Akt/Bcl-xL signaling and pancreatic beta-cell mass and protects against diabetes. FASEB Journal 22 3581-3594. (https://doi. org/10.1096/fj.08-111690)

Chiang YT \& Jin T 2014 p21-activated protein kinases and their emerging roles in glucose homeostasis. American Journal of Physiology: Endocrinology and Metabolism 306 E707-E722. (https://doi. org/10.1152/ajpendo.00506.2013)

Chiang YA, Shao W, Xu XX, Chernoff J \& Jin T 2013 P21-activated protein kinase 1 (Pak1) mediates the cross talk between insulin and beta-catenin on proglucagon gene expression and its ablation affects glucose homeostasis in male C57BL/6 mice. Endocrinology 154 77-88. (https://doi.org/10.1210/en.2012-1781)

Deisl C, Simonin A, Anderegg M, Albano G, Kovacs G, Ackermann D, Moch H, Dolci W, Thorens B, A Hediger M, et al. 2013 Sodium/ hydrogen exchanger NHA2 is critical for insulin secretion in beta-cells. PNAS 110 10004-10009. (https://doi.org/10.1073/ pnas.1220009110)

Feng AL, Xiang YY, Gui L, Kaltsidis G, Feng Q \& Lu WY 2017 Paracrine GABA and insulin regulate pancreatic alpha cell proliferation in a mouse model of type 1 diabetes. Diabetologia 60 1033-1042. (https:// doi.org/10.1007/s00125-017-4239-x)

Fujino T, Asaba H, Kang MJ, Ikeda Y, Sone H, Takada S, Kim DH, Ioka RX, Ono M, Tomoyori H, et al. 2003 Low-density lipoprotein receptor-related protein 5 (LRP5) is essential for normal cholesterol metabolism and glucose-induced insulin secretion. PNAS 100 229-234. (https://doi.org/10.1073/pnas.0133792100)

Garcia-Martinez JM, Chocarro-Calvo A, Moya CM \& Garcia-Jimenez C $2009 \mathrm{WNT} /$ beta-catenin increases the production of incretins by entero-endocrine cells. Diabetologia 52 1913-1924. (https://doi. org/10.1007/s00125-009-1429-1)

Grant SF, Thorleifsson G, Reynisdottir I, Benediktsson R, Manolescu A, Sainz J, Helgason A, Stefansson H, Emilsson V, Helgadottir A, et al. https://joe.bioscientifica.com

https://doi.org/10.1530/JOE-20-0109 (c) 2020 Society for Endocrinology Published by Bioscientifica Ltd. Printed in Great Britain 
2006 Variant of transcription factor 7-like 2 (TCF7L2) gene confers risk of type 2 diabetes. Nature Genetics 38 320-323. (https://doi. org/10.1038/ng1732)

Hansotia T, Baggio LL, Delmeire D, Hinke SA, Yamada Y, Tsukiyama K, Seino Y, Holst JJ, Schuit F \& Drucker DJ 2004 Double incretin receptor knockout (DIRKO) mice reveal an essential role for the enteroinsular axis in transducing the glucoregulatory actions of DPP-IV inhibitors. Diabetes 53 1326-1335. (https://doi.org/10.2337/ diabetes.53.5.1326)

Hino S, Tanji C, Nakayama KI \& Kikuchi A 2005 Phosphorylation of beta-catenin by cyclic AMP-dependent protein kinase stabilizes beta-catenin through inhibition of its ubiquitination. Molecular and Cellular Biology 25 9063-9072. (https://doi.org/10.1128/ MCB.25.20.9063-9072.2005)

Ip W, Shao W, Song Z, Chen Z, Wheeler MB \& Jin T 2015 Liver-specific expression of dominant-negative transcription factor 7-like 2 causes progressive impairment in glucose homeostasis. Diabetes 64 1923-1932. (https://doi.org/10.2337/db14-1329)

Jagasia R, Steib K, Englberger E, Herold S, Faus-Kessler T, Saxe M, Gage FH, Song H \& Lie DC 2009 GABA-cAMP response elementbinding protein signaling regulates maturation and survival of newly generated neurons in the adult hippocampus. Journal of Neuroscience 29 7966-7977. (https://doi.org/10.1523/JNEUROSCI.1054-09.2009)

Januzi L, Poirier JW, Maksoud MJE, Xiang YY, Veldhuizen RAW, Gill SE, Cregan SP, Zhang H, Dekaban GA \& Lu WY 2018 Autocrine GABA signaling distinctively regulates phenotypic activation of mouse pulmonary macrophages. Cellular Immunology 332 7-23. (https://doi. org/10.1016/j.cellimm.2018.07.001)

Jensen CB, Pyke C, Rasch MG, Dahl AB, Knudsen LB \& Secher A 2018 Characterization of the glucagonlike peptide-1 receptor in male mouse brain using a novel antibody and in situ hybridization. Endocrinology 159 665-675. (https://doi.org/10.1210/en.2017-00812)

Jin T 2016 Current understanding on role of the Wnt signaling pathway effector TCF7L2 in glucose homeostasis. Endocrine Reviews 37 254-277. (https://doi.org/10.1210/er.2015-1146)

Jin T \& Drucker DJ 1996 Activation of proglucagon gene transcription through a novel promoter element by the caudal-related homeodomain protein cdx-2/3. Molecular and Cellular Biology 16 19-28. (https://doi.org/10.1128/mcb.16.1.19)

Jin T \& Weng J 2016 Hepatic functions of GLP-1 and its based drugs: current disputes and perspectives. American Journal of Physiology: Endocrinology and Metabolism 311 E620-E627. (https://doi. org/10.1152/ajpendo.00069.2016)

Jo S, Chen J, Xu G, Grayson TB, Thielen LA \& Shalev A 2018 miR-204 controls glucagon-like peptide 1 receptor expression and agonist function. Diabetes 67 256-264. (https://doi.org/10.2337/db17-0506)

Kim YB, Kim WB, Jung WW, Jin X, Kim YS, Kim B, Han HC, Block GD, Colwell CS \& Kim YI 2018 Excitatory GABAergic action and increased vasopressin synthesis in hypothalamic magnocellular neurosecretory cells underlie the high plasma level of vasopressin in diabetic rats. Diabetes 67 486-495. (https://doi.org/10.2337/db17-1042)

Li J, Casteels T, Frogne T, Ingvorsen C, Honore C, Courtney M, Huber KVM, Schmitner N, Kimmel RA, Romanov RA, et al. 2017 Artemisinins target GABAA receptor signaling and impair alpha cell identity. Cell 168 86.e15-100.e15. (https://doi.org/10.1016/j. cell.2016.11.010)

Liu Z \& Habener JF 2008 Glucagon-like peptide-1 activation of TCF7L2dependent Wnt signaling enhances pancreatic beta cell proliferation. Journal of Biological Chemistry 283 8723-8735. (https://doi. org/10.1074/jbc.M706105200)

Liu W, Son DO, Lau HK, Zhou Y, Prud'homme GJ, Jin T \& Wang Q 2017 Combined oral administration of GABA and DPP-4 inhibitor prevents beta cell damage and promotes beta cell regeneration in mice. Frontiers in Pharmacology 8 362. (https://doi.org/10.3389/ fphar.2017.00362)
Masson E, Koren S, Razik F, Goldberg H, Kwan EP, Sheu L, Gaisano HY \& Fantus IG 2009 High beta-cell mass prevents streptozotocin-induced diabetes in thioredoxin-interacting protein-deficient mice. American Journal of Physiology: Endocrinology and Metabolism 296 E1251-E1261. (https://doi.org/10.1152/ajpendo.90619.2008)

Panjwani N, Mulvihill EE, Longuet C, Yusta B, Campbell JE, Brown TJ, Streutker C, Holland D, Cao X, Baggio LL, et al. 2013 GLP-1 receptor activation indirectly reduces hepatic lipid accumulation but does not attenuate development of atherosclerosis in diabetic male ApoE(-/-) mice. Endocrinology 154 127-139. (https://doi.org/10.1210/en.20121937)

Pettus J, Hirsch I \& Edelman S 2013 GLP-1 agonists in type 1 diabetes. Clinical Immunology 149 317-323. (https://doi.org/10.1016/j. clim.2013.04.006)

Purwana I, Zheng J, Li X, Deurloo M, Son DO, Zhang Z, Liang C, Shen E, Tadkase A, Feng ZP, et al. 2014 GABA promotes human beta-cell proliferation and modulates glucose homeostasis. Diabetes 63 4197-4205. (https://doi.org/10.2337/db14-0153)

Reich E, Tamary A, Sionov RV \& Melloul D 2012 Involvement of thioredoxin-interacting protein (TXNIP) in glucocorticoid-mediated beta cell death. Diabetologia 55 1048-1057. (https://doi.org/10.1007/ s00125-011-2422-z)

Rorsman P, Berggren PO, Bokvist K, Ericson H, Mohler H, Ostenson CG \& Smith PA 1989 Glucose-inhibition of glucagon secretion involves activation of GABAA-receptor chloride channels. Nature 341 233-236. (https://doi.org/10.1038/341233a0)

Scrocchi LA, Brown TJ, MaClusky N, Brubaker PL, Auerbach AB, Joyner AL \& Drucker DJ 1996 Glucose intolerance but normal satiety in mice with a null mutation in the glucagon-like peptide 1 receptor gene. Nature Medicine 2 1254-1258. (https://doi.org/10.1038/nm1196-1254)

Shalev A 2014 Minireview: thioredoxin-interacting protein: regulation and function in the pancreatic beta-cell. Molecular Endocrinology $\mathbf{2 8}$ 1211-1220. (https://doi.org/10.1210/me.2014-1095)

Shao W, Yu Z, Fantus IG \& Jin T 2010 Cyclic AMP signaling stimulates proteasome degradation of thioredoxin interacting protein (TxNIP) in pancreatic beta-cells. Cellular Signalling 22 1240-1246. (https://doi. org/10.1016/j.cellsig.2010.04.001)

Shao W, Wang Z, Ip W, Chiang YT, Xiong X, Chai T, Xu C, Wang Q \& Jin T 2013 GLP-1(28-36) improves beta-cell mass and glucose disposal in streptozotocin-induced diabetic mice and activates cAMP/ PKA/beta-catenin signaling in beta-cells in vitro. American Journal of Physiology: Endocrinology and Metabolism 304 E1263-E1272. (https:// doi.org/10.1152/ajpendo.00600.2012)

Shao W, Xiong X, Ip W, Xu F, Song Z, Zeng K, Hernandez M, Liang T, Weng J, Gaisano $\mathrm{H}$, et al. 2015 The expression of dominant negative TCF7L2 in pancreatic beta cells during the embryonic stage causes impaired glucose homeostasis. Molecular Metabolism 4 344-352. (https://doi.org/10.1016/j.molmet.2015.01.008)

Shao W, Szeto V, Song Z, Tian L, Feng ZP, Nostro MC \& Jin T 2018 The LIM homeodomain protein ISL1 mediates the function of TCF7L2 in pancreatic beta cells. Journal of Molecular Endocrinology 61 1-12. (https://doi.org/10.1530/JME-17-0181)

Soltani N, Qiu H, Aleksic M, Glinka Y, Zhao F, Liu R, Li Y, Zhang N, Chakrabarti R, Ng T, et al. 2011 GABA exerts protective and regenerative effects on islet beta cells and reverses diabetes. PNAS $\mathbf{1 0 8}$ 11692-11697. (https://doi.org/10.1073/pnas.1102715108)

Tian J, Dang H, Chen Z, Guan A, Jin Y, Atkinson MA \& Kaufman DL 2013 Gamma-aminobutyric acid regulates both the survival and replication of human beta-cells. Diabetes 62 3760-3765. (https://doi.org/10.2337/ db13-0931)

Trapnell C, Roberts A, Goff L, Pertea G, Kim D, Kelley DR, Pimentel H, Salzberg SL, Rinn JL \& Pachter L 2012 Differential gene and transcript expression analysis of RNA-seq experiments with TopHat and Cufflinks. Nature Protocols 7 562-578. (https://doi.org/10.1038/ nprot.2012.016) https://joe.bioscientifica.com https://doi.org/10.1530/JOE-20-0109 (c) 2020 Society for Endocrinology Published by Bioscientifica Ltd. Printed in Great Britain 
Untereiner A, Abdo S, Bhattacharjee A, Gohil H, Pourasgari F, Ibeh N, Lai M, Batchuluun B, Wong A, Khuu N, et al. 2019 GABA promotes beta-cell proliferation, but does not overcome impaired glucose homeostasis associated with diet-induced obesity. FASEB Journal 33 3968-3984. (https://doi.org/10.1096/fj.201801397R)

van der Meulen T, Lee S, Noordeloos E, Donaldson CJ, Adams MW, Noguchi GM, Mawla AM \& Huising MO 2018 Artemether does not turn alpha cells into beta cells. Cell Metabolism 27 218.e214-225.e214.

Xiang YY, Wang S, Liu M, Hirota JA, Li J, Ju W, Fan Y, Kelly MM, Ye B, Orser B, et al. 2007 A GABAergic system in airway epithelium is essential for mucus overproduction in asthma. Nature Medicine $\mathbf{1 3}$ 862-867. (https://doi.org/10.1038/nm1604)

Xu E, Kumar M, Zhang Y, Ju W, Obata T, Zhang N, Liu S, Wendt A, Deng S, Ebina Y, et al. 2006 Intra-islet insulin suppresses glucagon release via GABA-GABAA receptor system. Cell Metabolism 3 47-58. (https://doi.org/10.1016/j.cmet.2005.11.015)
Xu G, Chen J, Jing G \& Shalev A 2013 Thioredoxin-interacting protein regulates insulin transcription through microRNA-204. Nature Medicine 19 1141-1146. (https://doi.org/10.1038/nm.3287)

Xu Y, Chang JT, Myers Jr MG, Xu Y \& Tong Q 2016 Euglycemia restoration by central leptin in Type 1 diabetes requires STAT3 signaling but not fast-acting neurotransmitter release. Diabetes 65 1040-1049. (https://doi.org/10.2337/db15-1160)

Yi F, Brubaker PL \& Jin T 2005 TCF-4 mediates cell type-specific regulation of proglucagon gene expression by beta-catenin and glycogen synthase kinase-3beta. Journal of Biological Chemistry 280 1457-1464. (https://doi.org/10.1074/jbc.M411487200)

Zhou Y, Park SY, Su J, Bailey K, Ottosson-Laakso E, Shcherbina L, Oskolkov N, Zhang E, Thevenin T, Fadista J, et al. 2014 TCF7L2 is a master regulator of insulin production and processing. Human Molecular Genetics 23 6419-6431. (https://doi.org/10.1093/hmg/ ddu359)

Received in final form 5 June 2020

Accepted 15 June 2020

Accepted Manuscript published online 16 June 2020
(C) 2020 Society for Endocrinology Published by Bioscientifica Ltd. Printed in Great Britain 